\title{
Children and Disaster Risk Reduction and Management in the Context of the Rights-Based Approach to Development; the Cases of the Municipalities of Catarman and Laoang in the Province of Northern Samar
}

\author{
Juniver P. Delorino \\ Master of Arts in Development Policy
}

\begin{abstract}
This study attempted to investigate the extent of children's participation in the local disaster risk reduction and management (DRRM) programs and its contribution to their rights to development towards building their future individual preparedness in responding safely and responsibly to disaster and other emergencies. It also investigated the impact of their participation on their individual awareness, knowledge, skills, motivation, and attitude, in relation to DRRM. The overall goal of the study was to evolve policy recommendations toward strengthening the local DRRM and making them work as welfare-enhancing programs for the children and youth. The rights-based approach (RBA) to development, and the United Nations Convention on the Rights of the Child (CRC) provisions on participation, were made as reference in looking at the institutionalization of children's participation in DRRM. The study made use of a Conceptual Framework generally anchored on Institutional Analysis Development (IAD) model in describing the relationship of key variables under investigation. The variables of the study were grouped according to the framework's components, namely: exogenous variables, action arena, interactions, evaluative criteria and outcomes. The overall anchor of this study was the RBA, with emphasis on the partnership/collaboration between and among duty bearers - NGOs, Schools and MDRRMOs, and rights holders-the students. This study was conducted in the municipalities of Catarman and Laoang in the Province of Northern Samar. The Respondents include MDRRMOs, school heads of selected private and public primary and secondary schools, some local officials and parents, and some elementary students who are at Grade V and Grade VI, and all the year levels in the secondary level and selected NGO representatives. The range of activities under the local DRRM programs being institutionalized by the respondent-agencies include representation in decision-making in DRRM activities; organizing and mobilizing children's organizations; child-led risk assessment and training for delivering indigenous early warning system; child-led theatre presentations and cultural showsrelated to DRRM; film screenings and other point activities with teachers and school officials; coordinator of Earth Day and similar celebrations with other municipalities; tree planting and growing campaigns; support in management of marine protected and watershed areas; adopt a tree/watershed project; promotional and educational activities for disaster preparedness at school or in the community; first-aid and basic life support trainings; and community drills and disaster simulation exercises. The assessment by the students themselves showed that the first two most participated activities include "tree planting and growing campaign" and "community drills and disaster simulation exercises" while the least participated activity is "support in management of marine protected and watershed areas". The groupings of these option activities revealed that about 75 percent of the activities of which children were involved was under the "preparedness" phase of disaster management, while the remaining 25 percent belonged to the "mitigation" phase. Unfortunately, the local children have no participation in activities under the "recovery" and "response" phases of disaster management. In terms of the extent of institutionalization of children's participation, the school heads group revealed that more than one-half of the activities was moderately institutionalized, MDRRMOs group, about three-fourths, highly institutionalized; and the NGOs gave an assessment of moderately institutionalized to half to half of all the activities. Gauging the impact on the children of their participation in DRRM activities, it was shown based on their self-assessmentsthat they were moderately aware moderately knowledgeable, moderately skilled, moderately motivated, and neutral in attitude. A set relevant policy recommendations has been developed in response to critical gaps as drawn from the conclusion of the study towards enhancing local DRRM programs and making children's participation sustainable.
\end{abstract}

\section{Introduction}

The amount of damage and the impact disasters have on the economy and humanity is far too evident for governments to remain passive and indifferent from formulating initiatives for a safer community and prepared citizenry.

The increasing incidence of hazards and the impacts of disaster worldwide are undermining collective efforts towards alleviating global poverty, specifically in meeting the Millennium Development Goals (MDGs). The International
Monetary Fund (IMF) estimated that the average economic cost for each individual large scale natural disaster event was over 5 percent of the Gross Domestic Product (GDP) in low income countries between 1997 and 2001; recent World Blank estimates have placed this figure in the range of $2-15$ percent of GDP for low income countries (DFID, 2006).

In 2011, the Philippines' National! Disaster Risk Reduction and Management Council (NDRRMC) reported a total of 431 natural and human -induced disasters, leaving 1,774 people dead, and affected more than three million families or 15.3

Volume 6 Issue 12, December 2017

www.ijsr.net 


\section{International Journal of Science and Research (IJSR) \\ ISSN (Online): 2319-7064 \\ Index Copernicus Value (2016): 79.57 | Impact Factor (2015): 6.391}

million people while causing over Php26billion in economic damage (Philippine Disaster Report, 2011).

The Philippines normally experiences at least 20 typhoons a year but the recent years saw more disaster events that were influenced by climate change. The notable changes in the country include increasing temperature, rising sea level and increased frequency of extreme events. These changes eventually converted disaster-safe zones into areas that are at nature's mercy.

Moreover, being situated in highly seismic zone as it lying along the Pacific Ring of Fire, the country is also prone to earthquakes. The Philippine Institution of Volcanology and Seismology (PhilVolcs) reported an average of five earthquakes occurring in the country per day (FAO, undated) and their impact on the affected communities is it at times massive and devastating.

There are some of the urgent consideration for the country to adopt disaster risk reduction and management (DRRM). Laying the basis for a paradigm shift to DRRM from the disaster preparedness was the enactment of Republic Act 10121 otherwise known the Philippine Disaster Risk Reduction and Management Act of 2010. This is in support of the Philippines' commitment to achieve the targets set by the Millennium Development Goals (MDGs) and to build resilient communities as expressed by its adoption of the Hyogo Framework of Action (HFA) in 2005.

To mitigate the situation, disaster risk reduction (DRR) and disaster risk management (DRM) measures have been formulated at the international, national and local community levels. At the international scene, the HFA was launched at the World Conference on Disaster Reduction (WCDR) in 2005 by the 168 member states that issued the Hyogo Declaration in support of the HFA which aims to assist the efforts of nations and communities to become more resilient to natural hazards.

The potential of a hazard to become a disaster depends on the population's vulnerability or coping capacity. The poor women, the elderly or disabled, and children are often most vulnerable and therefore, the worst affected. Disasters do not just happen, they are a result of failures of development process which increase vulnerability and reduce coping capacities, containing development further in a "downward spiral". The goal of disaster risk reduction policy is to contribute to sustainable development through reducing the burden of disasters on the poor and most vulnerable (DFID, 2006)

Consequently, DRR and DRM efforts have been adopted by governments all over the world. As a means of incorporating DRR-related policies in national and local legislation, education has been identified as a venue in promoting to children the culture of preparedness to disasters and awareness to DRR policies. As a result of these efforts to institutionalize DRRM, it is has been deemed necessary to understand its concept, goals and functions.
In 2011, the United Nations (UN) defined DRR as the practice of reducing disaster risks through systematic efforts to analyze and manage the casual factors of disaster. There are many opinions with regard to what the casual factors of disasters are. However, the UN determines the casual factors, or "root causes" if disasters as the exposure to hazards, level of vulnerability of people and property, management of land and the environment, and level of preparedness for adverse events.

On the other hand, DRM is the process of using administrative decisions, organization, operational skills and capacities to implement policies, strategies and coping capacities of the society and communities to lessen the impacts of natural hazards and related environmental and technological disasters. It comprises all forms of activities, including structural and non-structural measures to avoid (prevention) or to limit (mitigation and preparedness) adverse effects of hazards (Disaster Risk Reduction Resource Manual, 2008). For brevity and convenience, DRMM is used to refer to both processes.

The National DRRM Plan charts some strategies such as building the adaptive capacities of communities, increasing the resilience of vulnerable sectors, and optimizing disaster mitigation opportunities in hopes of promoting people's welfare and security towards gender-responsive and rightbased sustainable development. To reinforce such strategies, the National Climate Change Action Plan (NCCAP) sets the agenda for climate change adaption and mitigation for 2011 to 2038. Consistent with the Climate Change Adaption (CCA) Framework, the NCCAP's ultimate goal is to "build the adaptive capacities of women and men in their communities, increase the resilience of vulnerable sectors and natural ecosystem to climate change and optimize mitigation opportunities towards gender-responsive and rights-based sustainable development.

Policies need to be implemented to mitigate the adverse effects of disasters and climate change. Aside from natural disaster, governments must also prepare for manmade disasters that may impact is people, environment and economy. Considering these, DRRM plans and policies have to incorporate parameters and procedures for both natural and man-made disasters to ensure compatibility, as well as to avoid wastage of funds, time and efforts between preparations and outcomes.

Amid this growing anxiety about disasters are children. Whatever approach is chosen to be undertaken, children's welfare and interests should remain as one of the top-most priorities. They should not remain passive victims of disasters nor as indirect beneficiaries of DRR initiatives. Rather, they should be capacitated and be made as active participants to such arrangements. As the most vulnerable and less prepared group, they need to be given attention by the government through promotion of develop men $t$ policies such as DRR campaigns that are intended to promote their rights and wellbeing.

\section{Volume 6 Issue 12, December 2017}

www.ijsr.net

Licensed Under Creative Commons Attribution CC BY 


\section{International Journal of Science and Research (IJSR) \\ ISSN (Online): 2319-7064 \\ Index Copernicus Value (2016): 79.57 | Impact Factor (2015): 6.391}

\section{Objectives of the Study}

Generally, this study attempted to determine how children's participation local disaster risk reduction and management programs contributed to their rights to development towards building their future individual preparedness in responding safely and responsibly to disasters and other emergencies.

Specifically, it hoped to achieve the following objectives:

1) To describe the profile-characteristics of the local DRRM programs.

2) To determine how children's participation in DRRM efforts and activities are institutionalized by concerned local government un its, elementary and secondary schools and other proponent organizations;

3) To discover how proponent agencies or organizations promoting or institutionalizing children's participation impact on the level of children's awareness, knowledge, skills, motivation , and attitude towards DRRM; and

4) To recommend policy reforms anchored on the major findings of this study towards strengthening the local DRRM programs and ensuring the sustainability of children's participation over the long term.

\section{Methodology}

Generally, the study was undertaken in the Province of Northern Samar which is one of the provinces comprising Samar Islands (the other two are Samar and Eastern Samar provinces). Northern Samar is bounded by the Pacific Ocean on the east, the San Bernardino Strait on the north, Samar Sea on the west, and the Samar and Eastern Samar provinces on the south. It ranks thirty-seventh $\left(37^{\text {th }}\right)$ in size among the 80 provinces of the Philippines and accounts for practically 1.2 percents of the total land area of the country. It is located at the eastern edge of archipelago with an area of 369,293 hectares. About 52 percents of the total land area is covered by forest and 42 percent is classified as alienable and disposable.

\section{Findings}

\section{Profile of the DRRM Programs}

The profile of the DRRM programs for the sample municipalities is characterized in terms of the proponents' agency, existence of the DRRM program, program title, budget and funding source, and provision of incentive and/or protection (Tables 1a; 1c to 1f).

The existence of the DRRM programs has been confirmed by the school heads, NGOs, and MDRRMO groups (Table 1b). The activities in said DRRM programs were mostly undertaken once a year or based on the availability of funding and the appropriateness of said activities to be held based on the school celebrations and national celebrations, e.g. National Fire Prevention Month, Earth Day, among others.
Table 1 (a): Proponent Agencies and its Collaborators

\begin{tabular}{|c|c|c|}
\hline $\begin{array}{l}\text { A. Proponent } \\
\text { Agency }\end{array}$ & Sample Institutions & $\begin{array}{c}\text { B. Collaborating } \\
\text { Agencies/Institutions }\end{array}$ \\
\hline \multirow{6}{*}{$\begin{array}{l}\text { Department of } \\
\text { Education }\end{array}$} & $\begin{array}{l}\text { Department of } \\
\text { Education-12 }\end{array}$ & \multirow{14}{*}{\begin{tabular}{|l} 
Bureau of Fire Protection \\
Department of Education \\
NGOs/CBOs/POs \\
Municipal of Barangay \\
Disaster Risk Reduction \\
Management Offices. \\
Armed Forces of the \\
Philippines \\
Philippine National \\
Police \\
Chalice \\
DSWD (PSWD/MSWD) \\
DILG (Brgy. Council \\
/Assoc. of Brgy Captains \\
DOH \\
DTI \\
Office of Civil Defense \\
(OCD) \\
Busines and Private \\
Sector
\end{tabular}} \\
\hline & $\begin{array}{l}\text { Elementary Schools } \\
\text { and } 7 \text { secondary }\end{array}$ & \\
\hline & $\begin{array}{l}\text { schools in the } \\
\text { Municipalities of }\end{array}$ & \\
\hline & Catarman and & \\
\hline & $\begin{array}{l}\text { Laoang, including } \\
\text { their respective }\end{array}$ & \\
\hline & $\begin{array}{l}\text { principal/school } \\
\text { heads }\end{array}$ & \\
\hline \multirow{4}{*}{$\begin{array}{l}\text { MDRRMO } \\
\text { of Catarman } \\
\text { MDRRMO } \\
\text { of Laoang }\end{array}$} & \multirow{4}{*}{$\begin{array}{l}\text { LGUs-Heads of } \\
\text { MDRRMOs } \\
\text { of the two } \\
\text { municipalities }\end{array}$} & \\
\hline & & \\
\hline & & \\
\hline & & \\
\hline \multirow[t]{3}{*}{$\begin{array}{l}\text { Philippine } \\
\text { Red Cross }\end{array}$} & \multirow{3}{*}{$\begin{array}{l}\text { NGOS-Heads of } \\
\text { PLAN } \\
\text { international } \\
\text { (Phils.) and Red } \\
\text { Cross }\end{array}$} & \\
\hline & & \\
\hline & & \\
\hline $\begin{array}{c}\text { PLAN } \\
\text { International }\end{array}$ & & \\
\hline
\end{tabular}

Table 1(b): Existence of DRRM Program for Children

\begin{tabular}{|c|c|c|}
\hline $\begin{array}{c}\text { Existence of DRRM } \\
\text { Program for Children }\end{array}$ & $\begin{array}{c}\text { With DRRM } \\
\text { Program }\end{array}$ & $\begin{array}{c}\text { Without DRRM } \\
\text { Program }\end{array}$ \\
\hline School Head & 19 & 0 \\
MDRRMO & 2 & 0 \\
NGOs & 2 & 0 \\
\hline
\end{tabular}

\section{Title and Status of DRRM Programs}

In terms of DRRM program/project titles, there were fifteen (15) titles presented and the earliest of which was implemented in 1947 (Disaster Management Services) and the least was in 2013 (School Disaster Risk Program). Notably, most of these programs have been implemented on a continuing basis (Table 1c).

Table 1 (c): Title and Status of DRRM Programs

\begin{tabular}{|c|c|c|}
\hline \multirow{2}{*}{ C. Title of DRRM Program } & \multicolumn{2}{|c|}{ Program Status } \\
\cline { 2 - 3 } & $\begin{array}{c}\text { Start of } \\
\text { Implementation }\end{array}$ & $\begin{array}{c}\text { Termination/ } \\
\text { Completion }\end{array}$ \\
\hline $\begin{array}{c}\text { Catarman I Central School Disaster } \\
\text { Risk Condition Management Program }\end{array}$ & 2012 & 2013 \\
\hline $\begin{array}{c}\text { Catarman SPED Disaster Risk } \\
\text { Reduction Program }\end{array}$ & 2013 & continuing \\
\hline $\begin{array}{c}\text { School Disaster Risk Reduction } \\
\text { Management program }\end{array}$ & 2013 & continuing \\
\hline Tree Planting and Growing Campaigns & 2010 & continuing \\
\hline $\begin{array}{c}\text { School-based DRRM Information } \\
\text { Drive }\end{array}$ & 2011 & continuing \\
\hline $\begin{array}{c}\text { School Disaster Management } \\
\text { Committee }\end{array}$ & 2011 & continuing \\
\hline The Environmentalists & 1999 & continuing \\
\hline
\end{tabular}

Volume 6 Issue 12, December 2017 


\section{International Journal of Science and Research (IJSR)}

ISSN (Online): 2319-7064

Index Copernicus Value (2016): 79.57 | Impact Factor (2015): 6.391

\begin{tabular}{|c|c|c|}
\hline $\begin{array}{c}\text { School-based Disaster Risk Reduction } \\
\text { Program }\end{array}$ & 2011 & 2016(5years) \\
\hline $\begin{array}{c}\text { Rawis Central School Disaster Risk } \\
\text { Reduction Program }\end{array}$ & 2010 & continuing \\
\hline \begin{tabular}{|c|} 
Disaster Risk Reduction Management \\
Program
\end{tabular} & $\begin{array}{c}\text { Start of } \\
\text { sponsorship }\end{array}$ & continuing \\
\hline UEPLLHS Disaster Programs & 2005 & continuing \\
\hline $\begin{array}{l}\text { Catarman National High School } \\
\text { Disaster Risk Program }\end{array}$ & 2012 & continuing \\
\hline School Disaster Risk Programs & 2013 & 2014 \\
\hline \begin{tabular}{|c|} 
Disaster Emergency Drills and \\
Exercises, Capability Building \\
Seminars of Municipalities Volunteers \\
on Rescue and Response, Celebrations \\
of National Disaster Consciousness \\
Month, Quarterly Meetings, Kampanya \\
Pagpangandamsa Kalamidad
\end{tabular} & 2011 & 2013 \\
\hline Disaster Management Services & 1947 & continuing \\
\hline BatangLigtas(Child Protect) & $\begin{array}{l}\text { From start of } \\
\text { program }\end{array}$ & continuing \\
\hline
\end{tabular}

\section{Program Funding/Budget}

In regard to budget (Table 1d), the school heads indicated that they have allocated budget (but no specific amounts were provided) taken from the school funds (MOOE and PTA) and PLAN Phils; the MDRRMO group indicated the Municipal Calamity Fund (MCF) as their source; and the NGO-from the Red Cross' donors and PLAN's national organizations.

Table 1d. Funding Source/Budget

\begin{tabular}{|c|c|c|c|}
\hline \multicolumn{4}{|c|}{ D. Funding Source } \\
\hline \multirow{2}{*}{ Respondents } & \multicolumn{2}{|c|}{ With Approved Budget } & $\begin{array}{l}\text { No Approved } \\
\text { Budget }\end{array}$ \\
\hline & Frequency & Funding Source & Frequency \\
\hline \multirow{2}{*}{$\begin{array}{l}\text { School } \\
\text { Heads }\end{array}$} & \multirow{2}{*}{19} & $\begin{array}{l}\text { School Funds (MOOE } \\
\text { and PTA) }\end{array}$ & \multirow[b]{2}{*}{0} \\
\hline & & \begin{tabular}{|c|} 
PLAN Phils. \\
Municipal Calamity Fund
\end{tabular} & \\
\hline MDRRMO & 2 & $\begin{array}{l}\text { PLAN National } \\
\text { Organizations }\end{array}$ & 0 \\
\hline NGO & 2 & Red Cross' Donors & 0 \\
\hline
\end{tabular}

\section{Program Components Involving Children}

The proponent-groups representing three institutions, namely the schools, local government units and NGOs, also assessed their respective DRRM programs as to component-activities involving children. The school heads ranked evacuation/ earthquakel firelflood drills first; lessons/integration in the curriculum, second, and the rest they ranked third (Table 1e).

Table 1(e): Program Components Involving Children

\begin{tabular}{|c|c|c|c|c|c|c|}
\hline \multicolumn{2}{|c|}{ E. Components Involving Children } \\
\hline & \multicolumn{2}{|c|}{$\begin{array}{c}\text { School } \\
\text { Heads }\end{array}$} & $\begin{array}{c}\text { MDRRM } \\
\text { Os }\end{array}$ & \multicolumn{2}{c|}{ NGOs } \\
\cline { 2 - 7 } Specific Activities & $\begin{array}{c}\text { Frequen } \\
\text { cy }\end{array}$ & $\begin{array}{c}\text { Ran } \\
\mathrm{k}\end{array}$ & $\begin{array}{c}\text { Frequen } \\
\text { cy }\end{array}$ & $\begin{array}{c}\text { Ran } \\
\mathrm{k}\end{array}$ & $\begin{array}{c}\text { Frequen } \\
\text { cy }\end{array}$ & $\begin{array}{c}\text { Ran } \\
\mathrm{k}\end{array}$ \\
\hline $\begin{array}{c}\text { Lecture or Awareness } \\
\text { campaign on DRR AND }\end{array}$ & & & & & & \\
Climate change & 2 & 3 & 1 & 1 & 0 & \\
Capacity-building/ & 2 & 3 & 2 & & 1 & \\
Capability Training & & & & & & \\
Film Showing & 2 & 3 & 0 & & 0 & 1 \\
\hline
\end{tabular}

Volume 6 Issue 12, December 2017 


\section{International Journal of Science and Research (IJSR)}

ISSN (Online): 2319-7064

Index Copernicus Value (2016): 79.57 | Impact Factor (2015): 6.391

meaningful participation in DRRM (Table 2.1a.1, 2.1a.2 and Table 2.1b)

Table 2.1 (a): Participation Identified by Students

\begin{tabular}{|c|c|c|}
\hline $\begin{array}{c}\text { List of DRRM-related activities participated in } \\
\text { by children }\end{array}$ & $\begin{array}{c}\text { Total } \\
\text { Frequency }\end{array}$ & Rank \\
\hline Tree planting and growing campaigns & 667 & 1 \\
\hline $\begin{array}{l}\text { Community drills and disaster simulation } \\
\text { exercises }\end{array}$ & 605 & 2 \\
\hline First-aid and basic life support trainings & 501 & 3 \\
\hline $\begin{array}{l}\text { Promotional and educational activities for } \\
\text { disaster preparedness at school or in the } \\
\text { community }\end{array}$ & 435 & 4 \\
\hline $\begin{array}{l}\text { Film screenings and other point activities with } \\
\text { teachers and school officials }\end{array}$ & 255 & 5 \\
\hline Adopt a tree/watershed projects & 220 & 6 \\
\hline $\begin{array}{c}\text { Representation in decisions-making in DRRM } \\
\text { activities }\end{array}$ & 217 & 7 \\
\hline $\begin{array}{l}\text { Organizing and mobilizing children's } \\
\text { organization }\end{array}$ & 180 & 8 \\
\hline $\begin{array}{l}\text { Coordination of Earth Day and similar } \\
\text { celebrations with other municipalities }\end{array}$ & 164 & 9 \\
\hline $\begin{array}{l}\text { Child-led risk assessment and training for } \\
\text { delivering indigenous early warning systems }\end{array}$ & 141 & 10 \\
\hline $\begin{array}{c}\text { Child-led theater presentation and cultural shows } \\
\text { related to DRM } \\
\end{array}$ & 133 & 11 \\
\hline $\begin{array}{l}\text { Support in management of marine protected and } \\
\text { watershed areas }\end{array}$ & 98 & 12 \\
\hline Other activities & 81 & 13 \\
\hline
\end{tabular}

\section{Groupings of DRRM Activities by Phases of Disaster Management}

Table 2.1c shows that nine (9) or 75 percent of the activities that were participated in by the local children belonged to the "preparedness" phase. While the remaining three (3) or 25 percent of the DRR activities were under the "mitigation" phase. The children have no involvement in the "recovery" and "response" phases of the local disaster management

Table 2.1(c): Classification of Children's DRRM-Related Activities by Phases of Disaster Management

\begin{tabular}{|c|c|}
\hline Activities & $\begin{array}{c}\text { Phase of } \\
\text { Disaster } \\
\text { Management }\end{array}$ \\
\hline Tree planting and growing campaigns & Mitigation \\
\hline $\begin{array}{l}\text { Community drills and disaster simulation } \\
\text { exercises }\end{array}$ & Preparedness \\
\hline First_-aid and basic life support trainings & Preparedness \\
\hline $\begin{array}{c}\text { Promotional and educational activities for disaster } \\
\text { preparedness at school or in the community }\end{array}$ & Preparedness \\
\hline $\begin{array}{c}\text { Film screenings and other point activities with } \\
\text { teachers and school officials Adopt a } \\
\text { tree/watershed projects }\end{array}$ & Preparedness \\
\hline $\begin{array}{l}\text { Representation in decisions-making in DRRM } \\
\text { activities }\end{array}$ & Mitigation \\
\hline $\begin{array}{l}\text { Organizing and mobilizing children's } \\
\text { organization }\end{array}$ & Preparedness \\
\hline $\begin{array}{l}\text { Coordination of Earth Day and similar } \\
\text { celebrations with other municipalities }\end{array}$ & Preparedness \\
\hline $\begin{array}{l}\text { Child-led risk assessment and training for } \\
\text { delivering indigenous early warning systems }\end{array}$ & Preparedness \\
\hline Child-led theater presentation and cultural shows & Preparedness \\
\hline
\end{tabular}

\begin{tabular}{|c|c|} 
related to DRM & \\
\hline $\begin{array}{c}\text { Support in management of marine protected and } \\
\text { watershed areas }\end{array}$ & Preparedness \\
\hline Other activities & Mitigation \\
\hline
\end{tabular}

\section{School Heads' Assessment of the Extent of Institutionalization of Children's Participation in DRRM}

On the school heads' assessment, of the range of optionactivities, bout 33 percent was rated "highly institutionalized" and these are "child-led theatre presentation and cultural shows "coordination of earth day and similar celebrations with other municipalities" "first aid and basic life support trainings: and "community drills and disaster simulation exercises". These activities obtained weighted mean valued ranging from 4.5 to 5.0.

"Moderately institutionalized" assessment was accorded to about 58 percent of the activities, ranging from the "representation in decision-making in DRRM", "organizing and mobilizing children's organizations" up to "promotional and educational activities for disaster preparedness at school or in the community". This group activities has a range of weighted mean values of 3.5 to 4.1 (Table 2.3).

The MDRRMOs Assessment of the Extent of Institutionalization of Children's

\section{Participation in DRRM}

Considering the very limited number of respondentMDRRMOs (only 2 of them), the results of their assessments on the extent of DRRM institutionalization may not give a realistic picture in relation to the actual situation on the field. Their evaluation revealed that about 75 percent was "moderately institutionalized" (Table 2.4)

NGOs' Assessment of the Extent of Institutionalization of Children's Participation in DRRM

The assessment of the NGO representatives presented a more spread ratings on the activities which ranged from "not institutionalized" to "highly institutionalized". More specially" "highly institutionalized" assessment was given 17 percent of the activities; "moderately institutionalized" to the 50 percent of the activities; "institutionalized" to two other activities (17\%); and another 17 percent was rated "less institutionalized". Only one (8\%) of the activities was assessed to be "not institutionalized" (Table2.5).

\section{Impact of Children's Participation}

The impact of the children's participation on their awareness, knowledge, skills, motivation and attitude in relation to DRRM programs were assessed by the same grouprespondents (Table 3a-3e).

This research sought for a comparative data between and among students, school heads, MDRRMOs and NGO representatives in terms of their respective assessment of the impact of children's participation in DRRM. The reason

Volume 6 Issue 12, December 2017 


\section{International Journal of Science and Research (IJSR) \\ ISSN (Online): 2319-7064 \\ Index Copernicus Value (2016): 79.57 | Impact Factor (2015): 6.391}

behind this comparative assessment is anchored on the idea that these stakeholders have a differing view on how children should participate. To consider the student's view alone would subject the study to biases of the students as children themselves and would have rendered this study as intrinsically flawed altogether.

Table 3 (a): Impact on Awareness

\begin{tabular}{|c|c|c|c|c|c|c|c|c|}
\hline \multirow{3}{*}{ Respondents } & \multicolumn{5}{|c|}{ Frequency } & \multirow{2}{*}{ Weighted } & Interpretation \\
\cline { 2 - 6 } & \multicolumn{5}{|c|}{ *level of Awareness } & & Mean & \\
\cline { 2 - 6 } & 1 & 2 & 3 & 4 & 5 & & 4.5 & highly aware \\
\hline NGO & 0 & 0 & 0 & 1 & 1 & 2 & 3.9 & moderately aware \\
Students & 0 & 0 & 0 & 9 & 4 & 13 & 3.7 & moderately aware \\
School Head & 46 & 80 & 187 & 226 & 347 & 886 & 3.7 \\
MDRRMO & 0 & 1 & 0 & 0 & 1 & 2 & 3.5 & moderately aware \\
\hline Average Weighted Mean 3.9 Moderately Aware
\end{tabular}

*4.2-5.0 highly aware; 3.4-4.1 moderately aware; 2.6-3.3 aware; 1.8-2.5 less aware; 1.0-1.7 not aware

Table 3 (b):.Impact on Knowledge

\begin{tabular}{|c|c|c|c|c|c|c|c|c|}
\hline \multirow{3}{*}{ Respondents } & \multicolumn{5}{|c|}{ Frequency } & \multirow{3}{*}{$\mathrm{N}$} & \multirow{3}{*}{$\begin{array}{c}\text { Weighted } \\
\text { Mean }\end{array}$} & \multirow{3}{*}{ Interpretation } \\
\hline & \multicolumn{5}{|c|}{ *level of Knowledge } & & & \\
\hline & 1 & 2 & 3 & 4 & 5 & & & \\
\hline NGO & 0 & 0 & 1 & 0 & 1 & 2 & 4.0 & moderately knowledgeable \\
\hline Students & 0 & 1 & 4 & 5 & 4 & 14 & 3.9 & moderately knowledgeable \\
\hline School Head & 26 & 81 & 194 & 359 & 248 & 908 & 3.8 & moderately knowledgeable \\
\hline MDRRMO & 0 & 1 & 0 & 1 & 1 & 2 & 3.0 & knowledgeable \\
\hline
\end{tabular}

*4.2-5.0 highly knowledgeable; 3.4-4.1 moderately knowledgeable; 2.6-3.3 knowledgeable; 1.8-2.5 less knowledgeable; $1.0-1.7$ not knowledgeable

Table 3 (c): Impact on Skill

\begin{tabular}{|c|c|c|c|c|c|c|c|c|}
\hline \multirow{3}{*}{ Respondents } & \multirow{2}{*}{\multicolumn{5}{|c|}{$\frac{\text { Frequency }}{* \text { level of Skill }}$}} & \multirow{3}{*}{$\mathrm{N}$} & \multirow{3}{*}{$\begin{array}{l}\text { Weighted } \\
\text { Mean }\end{array}$} & \multirow{3}{*}{ Interpretation } \\
\hline & & & & & & & & \\
\hline & 1 & 2 & 3 & 4 & 5 & & & \\
\hline $\mathrm{NGO}$ & 0 & 0 & 1 & 1 & 0 & 2 & 3.5 & moderately skilled \\
\hline Students & 0 & 0 & 1 & 1 & 0 & 2 & 3.5 & moderately skilled \\
\hline School Head & 63 & 120 & 269 & 254 & 160 & 866 & 3.4 & moderately skilled \\
\hline MDRRMO & 1 & 2 & 6 & 5 & 1 & 15 & 3.4 & moderately skilled \\
\hline
\end{tabular}

*4.2-5.0 highly skilled; 3.4-4.1 moderately skilled; 2.6-3.3 skilled; 1.8-2.5 less skilled; 1.0-1.7 not skilled

Table 3 (d): Impact on Motivation

\begin{tabular}{|l|c|c|c|c|c|c|c|c|}
\hline \multirow{3}{*}{ Respondents } & \multicolumn{5}{|c|}{ Frequency } & \multirow{2}{*}{ N } & Weighted & Interpretation \\
\cline { 2 - 7 } & \multicolumn{7}{|c|}{ *level of Motivation } & \\
\cline { 2 - 7 } & 1 & 2 & 3 & 4 & 5 & & Mean & \\
\hline NGO & 0 & 0 & 4 & 8 & 2 & 14 & 3.8 & highly motivated \\
Students & 0 & 0 & 1 & 4 & 0 & 2 & 3.5 & highly motivated \\
School Head & 65 & 133 & 265 & 238 & 169 & 870 & 3.4 & moderately motivated \\
MDRRMO & 0 & 0 & 2 & 0 & 0 & 2 & 3.0 & motivated \\
\hline Average Weighted Average 3.4 Moderately Motivated \\
\hline
\end{tabular}

*4.2-5.0 highly motivated; 3.4-4.1 moderately motivated; 2.6-3.3 motivated; 1.8-2.5 less motivated; $1.0-1.7$ not motivated

Table 3 (e):.Impact on Attitude

\begin{tabular}{|l|c|c|c|c|c|c|c|c|}
\hline \multirow{3}{*}{ Respondents } & \multicolumn{5}{|c|}{ Frequency } & \multirow{2}{*}{ Weighted } & Interpretation \\
\cline { 2 - 6 } & \multicolumn{7}{|c|}{ *level of Attitude } & \\
\cline { 2 - 5 } & 1 & 2 & 3 & 4 & 5 & & Mean & \\
\hline NGO & 0 & 0 & 0 & 2 & 0 & 2 & 4.0 & moderately positive attitude \\
Students & 0 & 1 & 4 & 9 & 0 & 14 & 3.6 & moderately positive attitude \\
School Head & 65 & 99 & 216 & 290 & 221 & 897 & 3.5 & moderately positive attitude \\
MDRRMO & 1 & 0 & 1 & 0 & 0 & 2 & 2.0 & negative attitude \\
\hline Average Weighte Average 3.3 Neutral Attitude \\
\hline
\end{tabular}

*4.2-5.0 highly positive attitude; 3.4-4.1 positive attitude; 2.6-3.3 neutral attitude; $1.8-2.5$ negative attitude; 1.0 -1.7 very negative attitude

Volume 6 Issue 12, December 2017

\section{www.ijsr.net}




\section{International Journal of Science and Research (IJSR) \\ ISSN (Online): 2319-7064 \\ Index Copernicus Value (2016): 79.57 | Impact Factor (2015): 6.391}

Recommendations Suggested by the Respondents-Groups

The following matrix (Table 4) lists the range of recommendations that were put forward by the concerned groups of respondents in the hope of enhancing the involvement children in DRRM programs. Of the 10 recommendations, the students' group gave the top most urgency to "motivate students that they can save others and self" and was rated rank 1. The second urgent recommendation is "budgetary support from the government". The "more promotion of the existence of the DRRM programs" ranked third among the range of recommendations. Interestingly, the students group elicited the highest number of recommendations over the other groups of respondents. This may reflect their understanding of the importance of DRRM and that they have started to embrace their potential roles in the program.

\section{Recommendations}

Summary.The proponents of DRRRM programs in the sample municipalities of Catarman and Laoang in the Province of Northern Samar include the Department of Education (DepEd), Local Government Units (LGUs), Non-Government Organizations (NGOs)-more specifically Philippine Red Cross and PLAN Philippines. Most of these agencies' DRRM Programs have components involving children and have been implemented on a continuing basis. Conversely, a number these programs were providing a range of incentive or protection for the participating children.

Apparently, there were only a number of agencies all collaborating institutions that have been tapped in institutionalizing children's involvement in DRRM in the Municipalities of Catarman Laoang. These proponent-agencies have been allocating fund for their DRRM programs or activities from specific sources. For instance, DepEd (schools) was getting part of their budget from the MOOEs, PTA funds and the PLAN Phils; LGUs through the MDRRMOs from the calamity funds; and NGOs (Red Cross and PLAN Phil) were sourcing out from PLAN national organizations and some donors organizations. These institutional funds, however, have been assessed by select group of key informants to be very inadequate vis-à-vis the aggregate funding needs for their DRRM programs to become sustainably operational and in turn capacitate children.

There is variable degree of implementation of programs and activities allowing children's participation in DRRM. Children were greatly involved in the physical or more tangible aspects of DRRM like community drills and disaster simulation exercises (rank 1) and tree planting and growing campaigns (rank 2 for both elementary and secondary students. On the other hand, representation in decision-making was ranked last by the elementary students and ranked seventh by the secondary students.

The range of activities under the local DRRM programs being institutionalized by the respondents-agencies include representation in decision-making in DRRM activities; organizing and mobilizing children's organization; child-led risk assessment and training for delivering indigenous early warning-systems; child-led theatre presentations and cultural shows related to DRRM; film screenings and other point activities with teachers and school officials; coordination of Earth Day and similar celebrations with other municipalities; tree planting and growing campaigns; support in management of marine protected and watershed areas; adopt a tree/watershed projects; promotional and educational activities for disaster preparedness at school or in the community; firstaid and basic life support trainings; and community drills and disaster simulation exercises.

So far, the first three rankings of these DRRM-related activities, which were mostly participated in by the children include the "tree planting and growing campaigns", "community drills and disaster simulation exercises" and "first aid and basic life support training".

The clustering of these DRRM activities by phases of disaster management showed that 95 percent of the option activities belonged to the "preparedness" phase while other 25 percent were under the "mitigation" category.

Interviews with key informants as well as follow-up interviews with school heads respondents revealed the absence of assessment and evaluation on the completed programs.

In terms of the extent of institutionalization of these activities involving children's participation, the school headrespondents indicated that 62 percent of these activities were moderately institutionalized. The MDRRMOs group gave an assessment that 45 percent were highly institutionalized while the NGO-respondents indicated that about 50 percent were moderately institutionalized.

Furthermore, with regard to the impacts of the institutionalization of the DRRM programs and activities, the children respondents themselves revealed that they are on the basis of awareness, knowledge, skills, attitude and motivationmoderately aware, moderately knowledgeable, moderately skilled;, neutral in attitude; and moderately motivated, respectively.

The municipal LGUs' institutionalization of children's participation in DRRM is still a work in progress. While Catarman has yet to implement children's participation, more importantly, it has to craft an MDRRMF in order to comply with the mandate of R.A. 10121. Laoang, on the other hand, had already started incorporating children's participation in DRRM. During the interviews however, there were admissions coming from key informants that the proposed budget specifying children's participation in DRRM was not yet included/implemented in the past year and this year.

\section{Conclusions}

Generally, the findings revealed that there was low children's participation in the DRRM-related activities because the

\section{Volume 6 Issue 12, December 2017}




\section{International Journal of Science and Research (IJSR) \\ ISSN (Online): 2319-7064 \\ Index Copernicus Value (2016): 79.57 | Impact Factor (2015): 6.391}

opportunities were practically not made available to them by concerned institutions, both public and private. This scenario has to some degree constrained the children groups from the exercise of their rights to participation in the development processes. Apparently, there have been some gaps that exist between the roles of the children and the concerned institutions. On the part of the institution, there were relatively poor exercise of their respective responsibility and accountability vis-ả-vis providing children access to participation in the local DRRM, as well as allowing them to be more involved in decision-making process.

The following are the specific inferences based on the problems presented:

1. In terms of proponents agencies and its collaborators, what can be gleaned is the lack of resourcefulness that had been exerted by respondent agencies in securing funding support from external sources. Specifically, there was over-reliance by the schools on its MOOEs and/or PTA funds which in essence impinges on the sustainability of DRRM programs.

That the current institutional DRRM budgets of the schools, local government units, and non-governments were very inadequate in relation to the total funding needs for their respective targeted DRRM activities. The limitation in budget has resulted in the weak or non-implementation of several of these DRRM activities which may have constrained children's involvement or participation.

Those programs with minimal budget were often ran on a yearly (to continuing) basis while those with big budget or established funding were ran on a 5-year term (to indefinite termination period). The respondents-school heads disclosed that this is based on the DRRM School Plan with is to be complied with on a yearly basis. Otherwise, clearances and/or salaries may be put on hold by the DepEd. In economic terms, minimal to zero budget is a threat to the sustainability of the programs.

The disinterest in conducting assessment and evaluation on the accomplished programs and activities in indicative of the needs for transparency and accountability mechanisms that are requisites for a more rights-based and sustainable undertaking. 2. That schools have a good number of DRRM-related activities in comparison with the LGUs and NGOs, and the most of these activities have some built-in incentive or protection component catering to children in particular. The very limited number of activities engaged in by the LGUs and NGOs may have something to do with their priority programs or thrusts at the time the study was conducted. Moreover, the low ranking received by "representation in decision-making in DRRM activities" from the students spoke of their perceptions that they should be more involved in decision-making for DRRM-related activities. It can be gleaned from the foregoing that children were made to be involvedin the "physical" component of DRRM activities, rather than the charactershaping or personality-defining or empowerment aspect of DRRM. The former set activities simply require physical involvement of children such as tree planting, Earth Day celebration, among others. The latter activities have to do with the development of children's capability and disaster preparedness. These agencies should as much as possible accord priority to these kinds of activities that would cultivate empowerment and at the same time enhance children's rights.

As duty bearers, the schools, LGUs and NGOs have failed to allow the children to make a meaningful participation within the context of the RBA. The children, for their part, have filed to demand entitlement to such a right (to participation). Even the SK, the representatives and alter-ego of the children within the political process went remiss in its obligation to be:1) accountable to the children with is failure to ensure that DRRM programs and activities were fully institutionalized; and 2) assert participation (as a matter of right)e.g. selection of programs to funs/implement.

3. That despite several moderately institutionalized DRRMrelated activities, only a few are actively participated in by the children groups. Also, the majority of these activities have been found to have limited number of children actually participating. This finding further strengthens the clamor among students for more DRRM projects and activities. There were only a few, interesting DRRM-related activities that children can participate in. children find the campaigns to be lacking in appeal since promotion of and awareness campaigns for these activities or programs were poorly executed.

4. That the impact of children's participation in DRRM-related activities upon themselves was still at a relatively moderate level which implies the necessity to increase or enhance their awareness, knowledge, skills, and attitude in relation to DRRM in general. Their heightened level on these parameters are necessary measures of their degree of empowerment and can immensely contribute as to how they will value their future involvement in DRRM-related activities.

5. That this study has provided some leads as to its contribution to child-based rights literature which generally embraces the inalienable rights of children in all circumstances including disasters when they are at their most vulnerable and the right to participate in decisions that ultimately affect them. The present state of the local DRRM with reference to children's participation is still relatively low in terms of institutionalization and resource-support and that serious efforts and allocation of the much-needed resources by the concerned government agencies and people's organizations have to be given top-most priority. Disaster risk reduction children about disaster risk and empowering them to use the knowledge that support life, survival and their development. Further, this study has specifically identified some kinds in the existing DRRM policies which have to be addressed through policy recommendation meant to ensure viable and sustainable participation of children in disaster in risk reduction efforts.

\section{References}

\section{Volume 6 Issue 12, December 2017}

www.ijsr.net

Licensed Under Creative Commons Attribution CC BY 


\section{International Journal of Science and Research (IJSR) \\ ISSN (Online): 2319-7064 \\ Index Copernicus Value (2016): 79.57 | Impact Factor (2015): 6.391}

[1] Ahrens, Joachim and Patrick M. Rudolf.2006, 'The Importance of Governance in Risk Reduction and Management, Journal Compilation, Blackwell Publishing Ltd.

[2] Alldred, P. 1999 "Ethnography and discourse analysis: Dilemmas in representing the voices of children in Feminist dilemmas in quantitative research: public voices. Private lives, eds. J. Ribbens\& R. Edwards.

[3] Arstein, Sherry. 1969, "A ladder of Citizen Participation', Journal of American Planning, Vol. 35, No. 4, pp. 216224.

[4] Back, E., Cameron, C. and Tanner, T. 2009. Children and Disaster Risk Reduction: Taking stock and moving forward, UNICEF with the Children in Changing Climate Consortium, Geneva.

[5] Bankoff, Greg. 2003,'Constructing Vulnerability: The Historical , Natural and Social Generation of Flooding in Metropolitan Manila,' Disasters, Volume 27, No. 3, pp.224-238.

[6] Brower, Ralph S. and Francisco A. Magno. 2011, 'A "Third Way" in the Philippines: Voluntary Organizing for a New Disaster Management paradigm,' International Review of Public Administration, Vol. 16, No. 1, pp 3150.

[7] Bureau of International Information Programs (BIIP) US Department of State.Human Rights in Brief, undated.

[8] Centers for Disease Control and Prevention (Child Development-Age grouping/Categories)http://www.cdc.gov/ncbddd/childdev elopment/positiveparenting/index.html Accessed on June $\underline{12}, 2013$

[9] Chawla, L.2001. Evaluating Children's Participation: Seeking Areas of Consensus.PLA Notes, Issue 42, pp.913, IIED London.

[10]Child-Centered DRR. Plan International. http://planinternational.org/filed/global/publications/emergencies/Ch ild_Centered_DRR-core-publication.pdf Accessed June 5,2013

[11]Child-Centered DRR Toolkit. Plan International www.childreninachangingclimate.org/database/plan/Publi cation/Child-Centered_DRR Toolkit.pdf Accesses on June 12, 2013

[12] Community-Based Monitoring System in Northern Samar and its implications on Governance and the Localization of the Millennium Development Goals, December 2010.

[13] Cook, Philip, Blanchet-Cohen, N. and Hart, Stuart. 2004. Children As Partners: Child Participation Promoting Social Change. International for Child Rights and Development The Canadian International Development Agency (CIDA) Child Protection Unit.

[14]Council for the Welfare of Children. 2009. State of the Filipino Children Report, Violence against Children.

[15]De Feyter, Karen. 2001. World Development Law. Antwerp: Intersentia.

[16] DFID. 2006. Reducing the Risk of Disaster-Helping to Achieve Sustainable Poverty Reduction in a Vulnerable World

[17] DFID.March. 2006. Disaster Risk Reduction Policy.
[18] Donnely, Mark. 2000. Global Governance and the New Wars: the Merging of Development and Security. London: Zed Books.

[19]FAO.On Solid Ground Addressing Land Tenure Issues Following

NaturalDisasters.http://www.fao.org/docrep/013/il255b/il 255b05.pdf

[20] Francis, Mark and Ray Lorenzo. 2002, 'The Seven Realms of Children's Participation, 'Journal of Environmental Psychology, 22, 157-169

[21] Frankovits, Andre and Patrick Earle (eds.). 2000. Working together: the Human Rights Based Approach to Development Cooperation. Report of the NGO Workshop. SIDA, Stockholm 16-19 October.

[22] Human Brigette L. A. 2001.Human Rights Approach to Development. Human Rights Quarterly 23.4, p 10051031.

[23]Hart, Roger A. 1997. Children's Participation: the Theory and Practice of involving Young Citizens in Community Development and Environmental Care.Earthscan: London

[24]Hart, Roger A. 1992. Children's Participation from Tokenism to Citizenship. Florence, Italy: UNICEF.

[25] Hernandez, Mario. 2000. Using Logic Models and Program, Theory to Build Outcome Accountability. Education and Treatment of Children, 23(1), 24-41.

[26] Human Rights Council of Australia (HRCA). 2001. Submission to the joint Standing Committee on Foreign Affairs. Defense and trade Inquiry into the Link between Aid and Human Rights. Canberra; HRCA.

[27] Implementing Rules and Regulations of Republic Act. No. 10121 also known as "An Act Strengthening the Philippine Disaster Risk Reduction and Management System, Providing for the National Disaster Risk Reduction and Management Framework and Institutionalizing the National Disaster Risk Reduction and Management Plan, Appropriating Funds Therefornand for other Purposes" http://www.ndrrmc.gov.ph/attachments/095 IRR.pdf Accessed on March 1, 2014

[28] Julian, David A. 1997. The Utilization of the Logic Model as a System Level Planning and Evaluation Device.Evaluation and Program Planning, 22\#(1),65-72.

[29]Lansdown, Gerison. 2001. Promoting Children's Participation in Democratic Decision-making. Florence, Ital: UNICEF. Leaño, Peter
Volume 6 Issue 12, December 2017

www.ijsr.net

Licensed Under Creative Commons Attribution CC BY 